(C) 2020 Katedra Białorutenistyki UW. Wydanie w otwartym dostępie na licencji CC BY-NC-ND (https://creativecommons.org/licenses/by-nc-nd/4.0/deed.pl)

ACTA ALBARUTHENICA 20: 2020

DOI: 10.32612/uw.18988091.2020.20.pp.111-122

Таццяна Кохан / Tatsiana Kokhan

Нацыянальная акадэмія навук Беларусі /

National Academy of Sciences of Belarus

ORCID: https://orcid.org/0000-0002-9696-2444

e-mail: taniakokhan@tut.by

\title{
Аповесці для маладых дзяўчат Яна Чачота ў кантэксце літаратуры для дзяцей і моладзі
}

NOVELS FOR YOUNG GIRLS by Jan Chachot in the context of literature for children and youth

POWIASTKI DLA MŁODYCH DZIEWCZĄT Jana Czeczota w kontekście literatury dla dzieci i młodzieży

Ч а працягу XIX стагоддзя ў многіх славянскіх краінах выспявала падхопленая ад еўрапейскіх асветнікаў ідэя стварэння літаратуры агульнанацыянальнага выхаваўчага значэння; асаблівая ўвага надавалася развіццю дзіцячай літаратуры. Індыкатарам новых павеваў стаў перыядычны друк, з’явіліся часопісы для дзяцей: „Rozrywki dla Dzieci”(пад рэд. Клемянціны Гофман з Таньскіx), „Tygodnik dla Dzieci” (выдаваўся Ігнацыем Каятанам Хжаноўскім і Станіславам Яховічам), „Dziennik dla Dzieci” (пад рэд. С. Яховіча), „Ziemomysł: Pismo czasowe dla Dzieci” (пад рэд. Яна Канты Хруцкага), „Skarbiec dla Dzieci”(пад рэд. Яна Леона Сянкевіча і Караля Казіміра Сянкевіча), „Zorza” (пад рэд. Паўліны Кракавовай). Перад літаратарамі паўстала задача стварэння аўтэнтычнай дзіцячай літаратуры, якая б адпавядала сусветнаму ўзроўню, аднак была заснавана на мясцовым матэрыяле. Для дасягнення пастаўленай мэты аўтары актыўна выкарыстоўвалі досвед і выхаваўча-адукацыйны патэнцыял фальклору, навукова-папулярнай, мастацкай і рэлігійнай кнігі. Паступова пачало фарміравацца кола прафесійных дзіцячых пісьменнікаў: "Mamy bajkopisarzy, poetów-pedagogów, którzy przeważnie działalność swoją autorską poświęcili dziatwie" [Osterloff 1893: 200]. Крытыкі адзначаюць і дастаткова разгалінаваную сістэму жанраў тагачаснай дзіцячай літаратуры:

W literaturze dla dzieci i młodzieży pod względem liczebnym najobfitszym jest dział powieściowy i poezji, składający się z przeróżnych powieści, powiastek, opowiadań, bajek, baśni, komedyjek i t. p., dalej idą podróże i nauki przyrodnicze, historja, elementarzyki obrazkowe i rozmaitości: jak zbiory powinszowań i t. p., wreszcie czasopisma [Książki dla dzieci... 1873/1874: 93]. 
Асаблівае месца сярод разнастайных твораў заняла маральная аповесць:

$<$...>powiastka moralna zajęła najpoważniejsze stanowisko w literaturze dla dzieci. Idąc za przykładem Hoffmanowej, pisarze w utworach dla dzieci starali się wysunąc na pierwszy plan morał, o rozpowszechnienie innych pożytecznych wiadomości, w powieściowej treści mniej dbano, o pobudzenie i rozwój fantazyi jeszcze mniej [Osterloff 1893: 200].

У сувязі з асаблівасцямі тагачаснага педагагічнага працэсу (наяўнасці розных падыходаў і праграм для хлопцаў і дзяуччат), для дзіцячай кнігі XIX стагоддзя характэрна выразнае гендарнае размежаванне.

Пісьменнікі актыўна працавалі над стварэннем адмысловай бібліятэчкі для дзяўчат, асаблівая патрэба адчувалася ў кнігах для прадстаўніц ніжэйшых слаёў грамадства: "Dla córki bowiem rolnika, rzemieślnika, lub wyrobnika pracowitego" [Campan 1827: I]. Часта аўтарамі кніжак для дзяўчат былі жанчыны (К. Гофман з Таньскіх, Ванда Малецкая, П. Кракавова). Верагодна, гэта звязана з прасякнутымі асаблівым даверам стасункамі маці-жанчыны і дачкі або настаўніцы і яе вучаніцы.

Выразным маральна-дыдактычным пафасам прасякнута творчасць Яна Чачота (1796-1847), пісьменніка беларуска-польскага памежжа, літаратурная спадчына якога належыць абодвум народам. У беларускім і замежным літаратуразнаўстве ідзе праца па асэнсаванні яго ролі ў літаратурным працэсе XIX ст., былі адшуканыя многія забытыя творы, асветленыя малазнаныя старонкі яго біяграфіi, распрацаваныя новыя навукова-метадычныя падыходы да разгляду яго мастацкага даробку. Тым не менш, зборнік Powiastki dla młodych dziewczą naśladowane $z$ dzieła Pani de Sęt (De Saintes, Delassemens de ma fille, 2 volumes ${ }^{1}$ ] [Anовесui для маладых дзяўчат, (наследаванне пані дэ Сэнт)] Я. Чачота да гэтага часу не аналізаваўся. Кніжка была выдадзеная ў 1845 годзе ў друкарні Юзэфа Завадскага з прысвячэннем дочкам Ігнацы Дамейкі: “Анэльцы, Зосі і Марыльцы Дамейкавым. Гэты асобнік аповесцяў, мной наследаваных, на памяць і духоўны спажытак. 16 жніўня 1844". Томік уключае чатыры аповесці: Świętochna albo Wdzięczność (Свянтохна, або Удзячнасць), Bogna i Lubomira albo Duma i Skromność (Богна і Любаміра, або Пыха і Сціпласць), Luidgarda albo Podróż pożyteczna (Людгарда, або Карыснае падарожжа), Dobrochna albo Dobrodziejstwo zawsze pamiętnie (Даброхна, або Дабрачыннасць заўсёды памятная), у аснове якіх знаходзіцца маральна-этычная праблематыка. Лёгка вылучыць элемент, які злучае ўсе вышэй названыя творы: іх галоўныя гераіні - дзяўчатыпадлеткі, чые думкі і паводзіны найбольш сугучныя мэтавай аўдыторыі выдання.

1 Аўтарства Алексіса Эймеры (1774-1854), кнігавыдаўца, гандляра, аўтара п’ес і розных выхаваўчых твораў для дзяцей. На сённяшні дзень імя А. Эймеры забыта, амаль усе кнігі былі зняты з продажу ў 1854 г., што прывяло да заўчаснай смерці пісьменніка. 
Вядомы навуковец Станіслаў Свірка называе яшчэ некалькі маральна-дыдактычных аповесцяў з празаічнага даробку Я. Чачота: Suknia Wyszywana (Вышываная сукенка), Zielone Trzewiczki (Зялёныя чаравічкі), Boże Narodzenie, uroczystość dla dzieci w Niemczech (Божае нараджэнне, урачыстасць для дзящей у Германіi) і Gęśle i rodzina wieśniaków normandzkich (Гуслі і сям'я нармандскіх вяскоўцаў), - якія, на думку даследчыка, з'яўляюцца перакладамі твораў розных замежных пісьменнікаў. Гэты томік Я. Чачот меркаваў прысвяціць К. Гофман з Таньскіх 2 . Аднак друкаваны асобнік гэтага зборніка, у адрозненне ад кнігі 1845 г., да гэтага часу не адшуканы, захаваўся толькі рукапіс. С. Свірка палічыў, што ўсе маральныя аповесці з'яўляюцца перакладной літаратурай, а таму не рабіў іх падрабязны аналіз у сваёй манаграфіi $Z$ Mickiewiczem pod rękę czyli życie i twórczość Jana Czeczota (Разам з Міцкевічам, або Жыццё і творчасць Яна Чачота).

На наш погляд, Аповесці для маладых дзяўчат - гэта аўтарскія творы Я. Чачота, напісаныя на ўзор французскіх тэкстаў. Пісьменнік наследаваў толькі форму, змяняючы і актуалізуючы змест. Яго гераіні, пераважна прадстаўніцы сярэдняга саслоўя, маюць тыповыя імёны, характэрныя для жыхароў былой Рэчы Паспалітай: [напрыклад, Свянтохна (скарочанае ад Святаслава), Любаміра, Даброхна (скарочанае ад Дабраслава)]. Аўтар нібыта сам вяртаецца у гады сваёй маладосці, згадвае тагачасныя рэаліі (музычныя салоны, дабрачынную дзейнасць біскупа Давіда Пілхоўскага, вайну 1812 года).

Безумоўна, Я. Чачот пераймаў папулярныя тэмы, якія існавалі ў сусветнай літаратуры, найперш, браў за ўзор шырока распаўсюджаны для таго часу вобраз станоўчай гераіні (асабліва растыражаваны пасля публікацыі рамана Сэм'юэла Рычардсана Pamela: Or, Virtue Rewarded, 1740 (Памэла, або Узнагароджаная дабрачыннасць). На нашу думку, менавіта $з$ публікацыяй гэтага рамана маральна-этычныя нормы і прынцыпы, на якіх павінна будавацца дзявочае выхаванне, знайшлі канцэптуальнае выражэнне ў вобразе дабрадзейнай гераіні.

Паэтыка твораў для дзяўчат сфарміравалася згодна з атмасферай эпохі, у выніку склаліся пэўныя кампазіцыйныя ўзоры, шаблоны. Так, асноўнымі рысамі маральных аповесцяў сталі дыдактызм, біяграфізм,

2 К. Гофман з Таньскіх (1798-1845) - дзіцячая пісьменніца. У 1819 г. выйшла першая аповесць Pamiq̨tka po dobrej таtсе (Памятка ад добрай маткі), у 1820 г. убачылі свет Powieści moralne (Маральныя аповесці). Стварыла бібліятэку для маленькага чытача Rozrywki dla Dzieci (Забаўкі для дзяцей, 1814-1828), у якой друкавала творы Мікалая Рэя, Яна Каханоўскага, Пятра Скаргі і інш. У 1829 г. пісьменніца выйшла замуж за Караля Гофмана, які далучыўся да Лістападаўскага паўстання, а пасля паражэння змушаны быў эміграваць у Францыю, разам 3 ім выехала і К. Гофман, якая і на эміграцыі працягвала сваю пісьменніцкую дзейнасць; там убачылі свет Nowe rozrywki dla dzieci (Новыя забаўкі для дзяцей), Nowa biblioteka poświęcona dzieciom i panienkom (Новая бібліятэка, прысвечаная дзецям і паненкам), Księżka do nabożeństwa dla Polek (Кніжка набажэнства для полек). Памерла ў 1845 г., пахаваная ў Парыжы. 
ідэалізацыя галоўнай гераіні. Фокус пісьменніцкай увагі быў скіраваны на станаўленне асобы і свядомасці гераіні; астатнія персанажы выступалі ў ролі адмысловых каталізатараў яе духоўнага росту. Можна адзначыць і наступную рысу - сюжэтную незавершанасць. Гераіні цікавяць аўтара толькі ў развіцці, пакуль праходзяць этапы свайго сталення (асабліва яскрава гэтая рыса выявілася ў аповесці Даброхна, альбо Дабрачыннасць заўсёды памятная, якая мае адкрыты фінал).

Арыентаваны на гуманістычныя каштоўнасці, Я. Чачот не мог ігнараваць ідэі часу, быў шчырым прыхільнікам асветніцкага вучэння аб выхаванні, сутнасць якога ў стварэнні гарманічна і уссебакова развітага чалавека. Услед за Джонам Локам і Жан-Жакам Русо, ён верыў, што мастацтва павінна выконваць выхаваўчыя функцыі і большасць грамадскіх праблем можна вырашыць шляхам асветы.

Таму праблематыку многіх твораў Я. Чачота (не толькі маральных аповесцяў) складае ідэя асветы як неабходная ўмова для развіцця гарманічнага чалавека і самога грамадства. Я. Чачот арыентаваўся на досвед сваіх папярэднікаў, запазычаючы ў іх не толькі пэўныя стэрэатыпныя калізіі, але і папулярныя ідэі. Працягваючы традыцыі Ж.Ж. Русо і сентыменталістаў, Я. Чачот разглядае дзіця як бязвінную істоту, a priori надзеленую добрым сэрцам. Гераіні маральных аповесцяў Я. Чачота (Даброхна, Свянтохна, Любаміра, Людгарда) - прыгожыя, працавітыя, усебакова развітыя, адукаваныя дзяўчаты, якія з'яўляюцца ўзорам дабрачыннасці, цноты і набожнасці.

Аўтар пазбягае паказу глыбокіх канфліктаў, усе перажыванні дзяўчат сканцэнтраваныя на паўсядзённым жыцці, сюжэтнае значэнне набывае сталенне і/ці ўдасканаленне гераінь. Асноўная тэма твораў свет дзявочых перажыванняў і інтарэсаў, звязаных з праблемай вызначэння месца і ролі ў сям'і і грамадстве.

Нягледзячы на тое, што ў аповесцях Свянтохна, або Удзячнасць, Богна і Любаміра, або Пыха і сціпласць менавіта галоўныя гераіні арганізуюць свет і персанажаў вакол сябе, прынцыповую ролю адыгрываюць ix духоўныя настаўніцы. 3 дапамогай добрых апякунак - пані Дабжыньскай (аповесць Свянтохна...) і пані Арман (аповесць Богна і Любамі$p a . .$.$) - дзяўчаты пераадольваюць усе выпрабаванні і знаходзяць сваё$ месца ў грамадстве і асабістае шчасце. Дабрадзейкі суправаджаюць дзяуччат ва ўсіх выпрабаваннях, спрыяюць духоўнаму сталенню і ствараюць умовы для далейшага развіцця і ўдасканалення. Вобраз дарослага як важны кампанент свету дзяцінства ўмацоўвае веру ў чалавека, яго дабрыню і міласэрнасць. Прасочваецца асноўная думка: дзіцяці патрэбна пэўнае атачэнне, уякім магчыма рэалізаваць закладзеныя ад прыроды добрыя пачаткі. У іншым выпадку нават добрыя ад прыроды дзеці становяцца сапсаванымі неналежным выхаваннем. Так сталася з Богнай, якую разбэсцілі заможныя бацькі. Пан Мажнецкі не заўважаў ніякіх недахопаў сваёй дачкі, чые паводзіны здаваліся яму дасканалымі: “Możniecki był tak w niej zaślepiony, iż nie postrzegał żadnego w niej 
błędu i co ona zrobiła, wszystko to mu się przedziwnym zdawało" [Czeczot 1845: 41], маці таксама ёй ва ўсім патурала: "Pani Możnecka, jej matka, niczego jej nie odmawiała, wszystko czołem przed nią biło" [Czeczot 1845: 39]. Сітуацыю не выправіла нават сямігадовае навучанне ў пансіёне пані Арман, "sławnej z dobrego wychowania dziewic" [Czeczot 1845: 31], бо Богна не была стараннай вучаніцай,

tak pisała, że chwała Bogu, jeśli w pisowni błędu nie zrobiła. Nauczyciel rysunku nie mógł nigdy nauczyć ją rysować nic więcej, prócz profilu głowy; ledwie umiała kilka mazurków i walców grać na fortepianie, które przecież lubiła; grała więc często, ale tak dziko, że biedny fortepian trzeba było ustawicznie nastrajać [Czeczot 1845: 35-36].

Да таго ж яна рэгулярна парушала рэжым:

Bogna brana prawie codziennie s pensionu do domu, odjeżdżająca w i powracająca w pysznej karecie, obdarzoną zawsze mnóstwem podarunków, któremi lubiła się chwalić i zadziwiać swoje towarzyszki, nabyła nałogu wymagać tonem rozkazującym wszystkiego, co się jej podobało i uważać z niejakąś pogardą towarzyszki mniej bogate [Czeczot 1845: 33].

Вынікам такога “выхавання” стала тое, што ў пятнаццацігадовым узросце Богну перапаўнялі пыха і пагарда да іншых: "przeto duma, wyniosłość i pogarda innych, w niej się podwoiły, a małpując starsze wiekiem osoby, piętnastoletnia Bogna starała się nadać sobie podobną im" [Czeczot 1845: 40-41].

У адрозненне ад Богны, чыё жыццё было напоўнена празмернай бацькоўскай любоўю і пяшчотай, сціплая і дабрадзейная Любаміра, дачка вайскоўца, не мела такіх выгод: ніхто не забіраў яе дадому, не прыносіў падарункі, не купляў прысмакі, і адзенне было занадта простым, хоць і чыстым. Нягледзячы на сацыяльную прорву, дзяуччаты пасябравалі: "Bogna i Lubomira uczyły się w jednej kłassie, mieszkały w jednym pokoju, igrały razem, słowem były w wielkiej zażyłości" [Czeczot 1845: 32]. Аднак замест таго, каб падтрымліваць сяброўку, Богна ўвесь час нібы здзекавалася з яе: “A twójże ojciec nicże ci nie przysyła?.. Jakże ty zawsze po prostu odziana! Nie uwierzysz, pokojówka mojej mamy piękniejsze ma suknie od twoich" [Czeczot 1845: 34]. Сітуацыя пагоршылася, калі ў Любаміры на вайне быў забіты бацька, дзяўчынка засталася самнасам са сваёй бядой: "Bez ojca, krewnych i przyjaciół została sierotą, kiedy najwięcej potrzebowała pomocy" [Czeczot 1845: 32]. Чулая да чужога гора пані Арман працягнула сваёй выхаванцы руку дапамогі:

P. Armanowa dając czuły wzgląd na położenie tej panienki była tak delikatną, iż nic nie chciała objawić jej o śmierci ojca i smutnych okolicznościach, w jakich ją zostawił; odkładając to do czasu, w którym Lubomira będzie dość usposobioną do utrzymania się na świecie z własnej pracy [Czeczot 1845: 32-33].

Нягледзячы на ўсе намаганні пані Арман, Любаміра ўсё ж даведалася аб смерці бацькі, аднак, каб нікому не рабіць прыкрасці, моўчкі перажывала сваё няшчасце. Яшчэ больш самотнай дзяўчынка адчула 
сябе, калі Богна скончыла навучанне і назаўсёды з’ехала з пансіёна: “Dni młodej sieroty upływały w smutku i tęsknocie" [Czeczot 1845: 38].

Пані Арман, занепакоеная душэўным станам сваёй выхаванкі, прапанавала напісаць да Богны. Любаміра з ахвотай узялася за напісанне ліста:

Kochana Bogno, pisała do niej Lubomira, wiek mi się zdaje, jakem ciebie niewidziała. Jakże mi czas leniwie idzie bez ciebie! Przyzwyczajona kochać cię i widzieć codziennie, nie mogę przywyknąć do twej nieobecności. Bądź szczęśliwa droga Bogno, oto jest najmilsze mojego serca życzenie [Czeczot 1845: 43].

Богна ледзь выціснула з сябе адказ, яна пашкадавала, што з-за маладога ўзросту не мае сакратаркі, а маці не захацела дапамагаць у гэтай складанай справе. У лісце, каб яшчэ больш уразіць пані Арман і Любаміру сваім багаццем, Богна запрасіла іх на вечар, на які збіраўся ці не ўвесь тагачасны бамонд, у тым ліку вядомы скрыпач Рэвут і спявачка Скібіньская.

Кантраснымі паўстаюць вобразы гераінь на кульмінацыйнай сустрэчы ў палацы Мажнецкіх: Любаміра была апранутая ў белую сукенку без гарсэту, сціплая кветка ўпрыгожвала светла-русыя валасы, Богна ж мела занадта адкрытае шыкоўнае ўбранне і такія ж раскаваныя паводзіны. Яшчэ не ведаючы пра тое, што бацька Любаміры памёр, Богна гучна ўсклікнула: "Półkownik! Piękny stopień! Lecz twój ojciec pewnie powróci jenerałem; przedziwnie! Będzie miał mundur cały od złota, jak ów, co tam siedzi jegomość" [Czeczot 1845: 51]. Сваімі нетактоўнымі размовамі Богна давяла Любаміру да слёз.

Варта адзначыць, што пры стварэнні дзявочых вобразаў пісьменнік не ўжываў прынцыпу катэгарычнага падзелу на "станоўчых" і “адмоўных", нават Богна не з'яўляецца безнадзейна сапсаванай дзяўчынкай, у канцы яна разумее ўсю недарэчнасць сваіх паводзінаў і просіць бацькоў, каб сірата Любаміра засталася жыць у іх сям'і.

На прыкладзе сябровак Я. Чачот паказаў, як сціпласць і добрае сэрца ўзвышаюць чалавека, у той час як багацце, дадзенае ад нараджэння, і адсутнасць належнага выхавання могуць сапсаваць нават бязвінную і чыстую душу дзіцяці, таму вышэйшую каштоўнасць маюць не падарункі сляпога лёсу, але толькі праца па самаўдасканаленні. Менавіта гэтую ключавую думку аповесці аўтар уклаў у вусны пані Арман: "Częstokroć ślepy traf daje bogactwa, lecz serce dobre i przymioty, którym skromność większą jeszcze nadaje cenę, winniśmy jedynie przyrodzeniu i własnej pracy" [Czeczot 1845: 34-35].

У аснове твора Свянтохна, або Удзячнасць таксама ляжаць праблемы выхавання маладога пакалення, жаночай адукацыі, узаемаадносін людзей у сям'і і грамадстве. Назва падкрэслівае абагульнена-сімвалічнае значэнне вобраза галоўнай гераіні, якая з'яўляецца персаніфікацыяй удзячнасці. Свянтохна, старэйшая дачка ў сям'і Мурграбяў, жыла ў Вільні. Прыгажосць дзяўчынкі не магла пакінуць нікога 
абыякавым: "Świętochna miała ładną twarzyczkę; z oczu żywych, czarnemi rzęsami przykrytych dowcip się wydawał, a długie czarne włosy spadające na białe ramiona zwracały uwagę na Świętochnę; zawsze się pytano: co to za piękna dzieweczka?" [Czeczot 1845: 10]. Нягледзячы на малы ўзрост, яна была дастаткова самастойнай, даглядала братоў і сястрычак, выконвала розныя даручэнні суседзяў і пані Дабжыньскай:

Dobra ta dziewczynka, mając ledwie lat ośm, już doglądała swych młodszych sióstr i braci i często spełniała polecenia mieszkańców domu. Nosiła tej pani listy na pocztę, przynosiła xiążki do czytania, a z rana śmietankę do kawy [Czeczot 1845: 9-10].

Старая пані заўважыла адказнасць і стараннасць дзяўчынкі, навучыла яе чытаць, пісаць, асновам веры, геаграфіі, гісторыі і маляванню, ужо ў 14 гадоў Свянтохне можна было смела даручыць выхаванне маладых паненак, нават сам яе выгляд мог быць для іх узорам:

Sama niestrojna przestawała na najskromniejszych sukienkach, które sobie zawsze uszyła: lecz tak jej wszystko było do twarzy, iż mówiono, że ją najmniejsza rzecz zdobi. Wspaniałe włosy zwite $\mathrm{w}$ długie upłoty rozwijające się nad głową, suknia bez gorsu, fartuszek z czarnej kitajki: oto jej zwyczajne ubiory. Lecz jak to wszystko czysto i gustownie, a bez wszelkiej przesady! [Czeczot 1845: 14-15].

Пані Дабжыньская ставілася да сваёй выхаванкі як да паненкі, кампаньёнкі, нават як да дачкі, такімі ж прыязнымі былі адносіны ўсіх астатніх персанажаў аповесці.

Аўтар у адносінах да гераіні выступае гісторыкам-хранікёрам, які занатоўвае станаўленне чалавека, сюжэтны рух аповесці абумоўлены звычайнымі акалічнасцямі прыватнага жыцця. Я. Чачот засяроджвае ўвагу на ўнутраным свеце гераіні, чые погляды і меркаванні нязменна выклікаюць павагу, хто б ні звяртаўся па дапамогу і падтрымку, яна ніколі і ні ў чым не адмаўляе. Калі ў старой пані збіраліся госці, то Свянтохна з прыемнасцю спявала песні, іграла на арфе, чытала вершы знакамітых паэтаў: "Niewiedziano czemu się bardziej dziwić: czy piękności wierszy, którym głos jej wdzięczny dawał tyle powabu, czy szlachetnym i pełnym natchnienia rysom jej oblicza, w których piękne dusza jaśniała" [Czeczot 1845: 12]. Пры гэтым сціплая Свянтохна лічыла, што ўсімі сваімі талентамі яна абавязана выключна пані Дабжыньскай: "Zawsze skromna i posłuszna, gdy ją obsypano pochwałami, żem czegoś warta, winnam to Pani Dobrzyńskiej" [Czeczot 1845: 12]. У той жа час дзяўчынка не забывалася на сваіх бедных бацькоў: "Myśl wówczas Świętochny szukała biednych rodziców mieszkających w szczupłym zakątku przy wschodach do salonu, w którym się sama odznaczała" [Czeczot 1845: 12] - i не цуралася ix: "Cnotliwa i pobożna Świętochna niezaniedbała nigdy pójżść w niedzielę z matką i z malemi braćmi do kościoła, ubrana skromnie, jak jej matka uboga" [Czeczot 1845: 12-13]. У вобразе Свянтохны, носьбіткі натуральнай дабрачыннасці, Я. Чачот увасобіў ідэал несапсаванай 
чалавечай натуры. Пісьменнік неаднаразова падкрэслівае яе заўчасную даросласць, адказнасць і дасканаласць:

Świętochna wtedy miała około lat szesnastu. W tym szczęśliwym wieku nikt nie myśli o biedzie; jednakże Świętochna była niespokojną i stroskaną. Zły stan zdrowia P. Dobrzyńskiej, ubóstwo rodziców Świętochny, los małych sióstr i braci, przychodziły jej na myśl ustawnie i pozbawiły pokoju [Czeczot 1845: 24-25].

У цяжкіх жыццёвых абставінах выяўляецца ўнутраная моц гераіні, якой трэба выбіраць паміж сям'ёй і старой пані. Так, калі заможная графіня прапанавала Свянтохне добрую працу з высокім заробкам, які б дазволіў забяспечыць сям’ю грашыма: “Płaca, którą ci przeznacza, dostateczną będzie dla wychowania twoich braci, osłodzisz też los biedny ojca twojego i matki" [Czeczot 1845: 21], - дзяўчынка адмаўляецца ад шыкоўнай прапановы, бо інакш ёй давялося б пакінуць хворую пані Дабжыньскую. Пачуццё абавязку вымагае ад дзяўчыны ахвяравання сваім будучым дзеля служэння пані: “Ty pani, której winnam życia mego szczęśliwość któraś mię nauczyła znać Boga, ludzi i siebie! Cóżbym bez twego wychowania umiała? I jaż miałabym cię opuścić? O nigdy!"[Czeczot 1845: 20].

Пачуццё абавязку узяяло верх над уласцівым рэальным людзям эгаізмам: “Żądaj życia mego, wnet je poświęcę dla ciebie” [Czeczot 1845: 21]. Высокамаральная, выхаваная, адукаваная Свянтохна не толькі здолела прайсці праз цяжкія выпрабаванні, захаваць усе станоўчыя рысы характару, яна знайшла сваё месца ў грамадстве. Свянтохна стала працаваць настаўніцай малявання і ігры на арфе ў пансіёне, які знаходзіўся побач 3 домам пані Дабжыньскай, што дазволіла па-ранейшаму апекавацца здароўем хворай дабрадзейкі і, як належыць ідэальнай дачцэ, падтрымліваць сваіх родных:

Tak je ujęta swemi przymiotami i talenty, że za ich pomocą bracia jej i siostry wszystkie oddane były na nauki, a ojciec otrzymał miejsce w pałacu pewnego pana na Wielkiej Ulicy, gdzie długo żył s swoją małżonką szczęśliwie, błogosławiąc niebu za dobre i pełne wdzięczności ku dobroczyńcom swym dziecie [Czeczot 1845: 27].

Я. Чачот стварае мадэль справядлівага свету, дзе дабрыня, спагадлівасць, выхаванасць і адукаванасць з'яўляюцца асноўнымі крытэрыямі для набыцця шчасця.

Яшчэ адным важным паказчыкам чалавечнасці з'яўляецца стаўленне да жывёл. Гэтая тэма стала цэнтральнай у аповесці Даброхна, альбо Дабрачыннасць заўсёды памятная, галоўная гераіня якой "młoda dziewczyna, osierocona od ojca miała matkę wcale niedostatnią. Rodzice jej otrzymali byli dosyć nie złe wychowanie i sami ile mogli starali się okrzesać milą Dobrochnę, swe dziecię jedyne [Czeczot 1845: 77].

Вобраз дзяўчынкі, на першы погляд, добра ўпісваецца ў жанравую мадэль маральнай аповесці: "Dobrochna nietak piękną, jak bardzo przyjemną miała twarzyczkę, w której się czułość małowała. Łagodna, oszczędna 
obdarzona była szczęśliwym charakterem. Nigdy matka nie miała potrzeby dwa razy jednej rzeczy jej zalecać" [Czeczot 1845: 77].

Пісьменнік падкрэслівае яе дабрыню і спагадлівасць: "Dobrochna miała serce zbyt czułe i litościwe" [Czeczot 1845: 78]. Дзяўчынка чым магла дапамагала абяздоленым: “<...> jeśli jej się zdarzyło widzieć ubogiego, to zaraz mu choć połowę swego śniadania, albo i całe oddawała" [Czeczot 1845: 78], з зацятасцю абараняла ад здзекаў жывёл. У той жа час, пісьменнік парушае рамкі стэрэатыпаў, у адрозненне ад большасці бездакорна паслухмяных гераінь маральных аповесцяў, Даброхна выступае як самастойная асоба, здольная да прыняцця рашэнняў. Нават разважлівыя папярэджанні дарослых аб небяспецы такіх паводзінаў не маглі яе перамяніць: "Napróżno rodzice mówili: ależ Dobrochno nadto się już zaciekasz w obronie psa, lub kota; możesz na tem wyjść nie osobliwie: pies może ukąsić, koty są zdradzieckie i skryte; za całe podziękowanie mogą ci czasem wydrzeć oczy" [Czeczot 1845: 78-79].

Аднойчы Даброхна ўбачыла, як некалькі хлопчыкаў здзекаваліся з сабачкі, для таго каб выратаваць бязвінную істоту з рук катаў, яна аддала ім усе свае грошы: "Dobochna mając tylko wszystkiego dziesięć groszy oddała je dla okupienia życia pieska" [Czeczot 1845: 79]. Пісьменнік падкрэслівае, што не толькі людзі, але і жывёлы адчуваюць дабрыню і могуць быць удзячнымі: "Dobrochna bierze od nich pieska, który jakby zgadując, że z rąk okrutników w ręce wybawczyni przechodzi, pobiegł za Dobrochną ruszając z radości ogonem" [Czeczot 1845: 79]. Узяўшы на сябе адказнасць за жыццё сабачкі, дзяўчынка не змагла пакінуць яго на вуліцы, аднак і паведаміць маці пра яго было складана: “<...>mama nie bardzo się lubiła zatrudniać kotami i psami, które trzeba było karmić, i które często przez nieochędóstwo meble zabrudzają" [Czeczot 1845: 80]. Нічога не сказаўшы сваёй маці, пані Кляноўскай, Даброхна схавала сабачку ў сваім пакоі і дзялілася з ім ежай. Некалькі тыдняў Азор жыў у схованцы, нікому не трапляючыся на вочы, часам ён суправаджаў Даброхну, калі дзяўчынка ішла на рынак ці ў краму за прадуктамі.

У адзін з такіх паходаў Добрахна ледзь несла цяжкі кошык, даверху напоўнены правіянтам, села адпачыць і на хвілінку выпусціла 3-пад увагі рэчы. Калі ж спахапілася, то ні кошыка, ні Азора не было. Разгубленая, яна вырашыла, што хтосьці скраў яе кошык, а Азор пабег дадому. Якое ж было здзіўленне, калі на прыступках Добрахна ўбачыла страчаныя рэчы і свайго вернага сабачку. Яна зразумела, што гэта Азор, каб ёй дапамагчы, сам данёс рэчы. Добрахна больш не магла захоўваць таямніцу і з радасцю расказала маці пра незвычайнага і разумнага сябра. Так нечакана высветлілася, што Азор вельмі кемлівы, ведае шмат розных каманд, з таго часу ён заўсёды стаў суправаджаць Даброхну і яе маці, калі яны выходзілі ў горад. Штораз сабачка пацвярджаў адданасць і ўдзячнасць сваёй гаспадыні: “Owoż jak to dobrodziejstwo nigdy nie jest stracone” [Czeczot 1845: 85]. Насуперак чаканням чытачоў, пісьменнік не стаў завяршаць аповед на гэтай аптымістычнай ноце. Далейшае 
развіццё сюжэта не мае выразных вузлавых момантаў. Акцэнт змяшчаецца на адлюстраванне складанага жыцця гераіні, поўнага цяжкасцяў, для аўтара было важным падкрэсліць выключную маральную чысціню гераіні, якая, нягледзячы на сваю беднасць, падавала міласціну яшчэ больш няшчасным: "Dobrochna chociaż uboga, była szczęśliwa. Ubóstwo niepozbawiało jej przyjemności udzielania biedniejszym pomocy" [Czeczot 1845: 86]. Фактычна развіццё дзеяння аповесці было скончана вышэй згаданай сентэнцыяй пра дабрачыннасць, таму фінал аповесці з'яўляецца адкрытым: "Reszty powiastki niedostaje, którą łaskawe czytelniczki podług myśli i uczuć swoich dokończyć mogą" [Czeczot 1845: 88].

У адрозненне ад вышэй названых твораў, аповесць Людгарда, або Карыснае падарожжа, мае іншую мастацкую прыроду. Аўтар стварае ілюзію дакументальнай дакладнасці матэрыялу, адводзячы сабе сціплую ролю "выдаўца" ліста, у якім маладая гераіня грунтоўна апісвае культуру, побыт і прыроду французскага горада Сэнт-Эцьен. У тэксце прысутнічаюць аўтарскія рэмаркі: "Niemało matek s córkami jeździ za granicę; mało matek i córek przywozi co stamtąd dobrego. Mowa ojczysta skażona, próżna szkatuła, nieco modnych kapeluszy i strojów: oto podarunki przywożone do kraju" [Czeczot 1845: 57]. Пісьменнік выступае супраць наследавання чужым традыцыям і модзе, супраць бяздумнага марнатраўства, для яго падарожжа - гэта найперш выдатная магчымасць даведацца пра чужую культуру і прывезці карысныя веды ў свой край, гэтую ж думку падхопіць і разаўе ў гутарцы Garść pszenna (Жменя пшаніцы) Уладзіслаў Сыракомля. Я. Чачот ухваляе Людгарду за цікавасць да звычаяў і побыту французаў:

Ciągle zajęta staraniem około matki, miała jednak czas przypatrywać się ob.cym krajom i ludom, zastanawiać się nad ich obyczajami, przemysłem i bytem, i przejęta miłością ziemi ojczystej często udzielała swojej przyjaciółce Aldonie wiadomości nie o modach i zabawach; ale o pożytecznych wynalazkach, kunsztach i rękodziełach, któreby rada była widzieć w swej ojczyznie [Czeczot 1845: 58].

Арыентацыя на адрасата, маладзенькую дзяўчынку Альдону, дазваляе Я. Чачоту адаптаваць складаны жанр падарожжа для дзіцячага ўспрымання: “Kochana Aldono, otożeśmy w Monbrizon. Nim tobie doniosę o tem mieście, chciałabym coś powiedzieć, cośmy widziały w Sę-Etję. Znajdziesz może w mym liście szczegóły mniej potrzebne, ale wszystkie mogą być zajmujące pożytecznie" [Czeczot 1845: 58]. Час ад часу пісьменнік ажыy̆ляе аповед воклічамі тыпу: “Mamyż się dziwić, kochana Aldono?" [Czeczot 1845: 66], “Gdybyś ty droga Aldono widziała” [Czeczot 1845: 71] і г. д.

Я. Чачот ускладняе нарацыйную структуру аповесці: акрамя вобраза аўтара і Людгарды, ён уводзіць у тэкст персанаж жыхара СэнтЭцьена пана Сміта, адваката і вучонага. Пан Сміт знаёміць Людгарду з гісторыяй і сучаснасцю горада, а дзяўчынка ў сваю чаргу пераказвае цікавую інфармацыю Альдоне. у творы адлюстроўваюцца рэальны свет і сапраўднае жыццё: конная чыгунка, зброевая фабрыка, школа 
гарнякоў, розныя мануфактуры і будынкі. Аўтар не абмінае ўвагай дзіцячую і жаночую працу. Пісьменнік і тут выступае за ўзвышэнне статусу жанчыны, гаворыць пра яе актыўны ўдзел у вытворчасці: “Jakie też było nasze wzruszenie, gdybyśmy ujrzały kobiety, których ręce zdają się być przeznaczone do lżejszych robot, ciągnące zębatą pilę po opierającem się ich usiłowaniom żełezie, albo uderzające częstemi razy w brzękliwe kowadło!" [Czeczot 1845: 68]. Я. Чачот не замоўчвае і праблемы прамысловага горада: цяжкія ўмовы жыцця кавалёў, хваробы працаўнікоў, бруднае паветра:

Kowale wyrabiający sprzęty żelazne, są w ogólności bardzo niechędóżni, co jest źródłem wielu chorób miejscowych; kowale ci tak niewygodnie mieszkają, mianowicie w niektórych ulicach, iż w jednej małej i brudnej izdebce do dziesiątka osób liczyć ich można. W ogólności powietrze w Sę-Etjenie nie jest czyste, najpospoliciej tumanem dymu napełnione [Czeczot 1845: 74].

Эпісталярная форма дазволіла Я. Чачоту максімальна элімінаваць вобраз аўтара, стварыць ілюзію дзіцячага аповеду пра падарожжа.

Такім чынам, зборнік Аповесці для маладых дзяўчат Я. Чачота, натхнёны творчасцю пані дэ Сэнт (Алексіс Эймеры) і К. Гофман з Таньскіх, арганічна ўпісваецца ў парадыгму дзіцячай літаратуры XIX ст. Характэрнымі рысамі аповесцей з'яўляюцца: дыдактызм, біяграфізм, ідэалізацыя галоўнай гераіні і сюжэтная незавершанасць.

Змест і структура зборніка падпарадкоўваюцца асноўнай педагагічнай задачы - дзявочаму выхаванню, фарміраванню высокіх этычных і эстэтычных норм і ідэалаў. Пры стварэнні вобразаў Свянтохны, Любаміры, Даброхны і Людгарды аўтар арыентаваўся на літаратурныя шаблоны, што прадвызначыла некаторы схематызм галоўных гераінь. Адукаваныя, разумныя, добра выхаваныя і набожныя, яны з'яўляюцца эталонам дзявочых паводзінаў.

\section{Бібліяграфія}

[b. a.] Książki dla dzieci, dla ludu i szkolne. „Warszawski rocznik literacki”. Rok 3. (1873). 1874: 93-95.

Cz...t Jan. 1845. Powiastki dla młodych dziewcząt naśladowane z dzieła Pani de Set (De Saintes, Delassemens de ma fille, 2 volumes). Wilno: druk. J. Zawadzkiego.

Campan Jeanne Louise. 1827. Rady dla młodych dziewcząt. Warszawa: druk. A. Brzeziny. Osterloff W. 1893. Najnowsza literatura. "Ateneum" t. 2, zeszyt 1: 200-205.

ABSTRACT: This article is an attempt to determine Jan Chachot's role in 19th century children's literature. Our main focus is placed on his almost unknown collection Novels for young girls, that consists of four novels: Sventochna, or Gratitude, Bogna and Lubomyra, or Arrogance and Modesty, Ludgarda, or the Useful travel, Dobrochna, or Charity always memorable. Their main characters are clever, beautiful, industrious, well-educated girls, who are veritable models of piety, charity and chastity. The basic theme of novels is the girl girls'world, related to their role in the family and society. Jan Chachot used the experience of his predecessors, adopting some of their ideas. As opposed to previous epochs, where 
the role of women was limited to their domestic duties and unqualified work, and female education was considered unnecessary and even harmful, Jan Chachot emphasizes that they can not only serve their family, but also be useful to society.

KEYWORDS: children's literature of $19^{\text {th }}$ century, moral story, ethical ideal, moral standard, Jan Chechot.

STRESZCZENIE: Artykuł poświęcony jest określeniu roli Jana Czeczota w literaturze dla dzieci XIX wieku. Główna uwaga zostaje skierowana na niezbadane dzieło Powiastki dla młodych dziewcząt naśladowane z dzieła Pani de Sęt (De Saintes, Delassemens de ma fille, 2 volumes ), które obejmuje cztery utwory: Świętochna albo Wdzięczność, Bogna i Lubomira albo Duma i Skromnośc", Luidgarda albo Podróż pożyteczna, Dobrochna albo Dobrodziejstwo zawsze pamiętnie. Ich bohaterki to inteligentne, piękne, pracowite, wykształcone dziewczyny, które są prawdziwymi wzorcami pobożności, miłości i czystości. Tematem przewodnim dzieła są doświadczenia i zainteresowania dziewcząt, związane z kwestią określania miejsca i roli w rodzinie i społeczeństwie. Jan Czeczot wykorzystał doświadczenia swoich poprzedników, zapożyczając od nich konflikty fabularne i pewne idee. W przeciwieństwie do poprzednich epok, w których rola kobiety była ograniczona obowiązkami rodzinnymi i pracą nisko wykwalifikowaną, a wykształcenie kobiet uważano za zbędne, a nawet szkodliwe, Jan Czeczot podkreśla, że kobiety mogą służyć nie tylko rodzinie, ale także przynosić pożytek społeczeństwu.

SŁOWA KLUCZOWE: literatura dla dzieci XIX wieku, powiastka moralna, ideał etyczny, norma moralna, Jan Czeczot.

РЭЗЮМЭ: Артыкул прысвечаны вызначэнню ролі Яна Чачота ў дзіцячай літаратуры XIX стагоддзя. Асноўная ўвага была звернута на амаль недаследаваны зборнік Аповесці для маладых дзяўчат, які складаецца з чатырох твораў: Свянтохна, або Удзячнасць, Богна і Любаміра, або Пыха і Сціпласць, Людгарда, або Карыснае падарожжа, Даброхна, або Дабрачыннасць заўсёды памятная. Іх галоўныя гераіні - разумныя, прыгожыя, працавітыя, адукаваныя дзяўчаты, якія з'яўляюцца сапраўдным узорам набожнасці, дабрачыннасці і цноты. Асноўная тэма твораў - свет дзявочых перажыванняў і інтарэсаў, звязаных з праблемай вызначэння месца і ролі ў сям'і і грамадстве. Я. Чачот выкарыстоўваў досвед сваіх папярэднікаў, запазычаючы ў іх сюжэтныя калізіі і некаторыя ідэі. У адрозненне ад папярэдніх эпох, дзе роля жанчыны (асабліва 3 ніжэйшых слаёў) абмяжоўвалася сямейнымі абавязкамі і нізкакваліфікаванай працай, а жаночая адукацыя лічылася непатрэбнай і нават шкоднай, Я. Чачот падкрэслівае, што дзяўчаты могуць не толькі служыць сям'i, але і прыносіць карысць грамадству.

кЛючАВыя словЫ: дзіцячая літаратура XIX стагоддзя, маральная аповесць, маральна-этычны ідэал, Ян Чачот. 